\title{
Analisis Kinerja dan Kemampuan Daerah dalam Pelaksanaan Otonomi Daerah Kota Pontianak
}

\author{
Atria Tiffany Widyaningsih* \\ Akademi Perpajakan Panca Bhakti
}

\begin{abstract}
Discussion about the Regional Financial Performance and Capabilities required to be processed more deeply, then becomes a problem in this research are: the financial capacity of the region in the implementation of regional autonomy, especially in 2011-2014, when viewed from the degree of decentralization Fiscal Indicators (DDF), Degree of Fiscal Autonomy (DOF), Fiscal Capacity, Needs Fiscal Effort / Effectiveness Ratio Fiscal Position original revenue (PAD) and Tax Performance Indicators and Local Retribution in Pontianak. And will be discussed also about the level of local financial independence in 2011-2014 to support the organizers of regional autonomy as measured by the ratio of Regional Financial Independence and Relationship Patterns in Pontianak. Research conducted at the Office of Pontianak City BPKAD, with the quantitative descriptive analysis method which uses data measured in a numerical scale / number. (Kuncoro, 2003) This analysis aims to determine the level of local financial capacity, level of independence and the readiness of the local government of the city of Pontianak in the implementation of regional autonomy. Results from this study and the performance of Financial Ability in one regional assessed from the ratio of local independence that describes to the extent of financial dependence of local governments to the central government, obtained by comparing the acceptance of PAD to acceptance Assistance and Contribution Regions. From the year 20112014, the average calculation independence ratio Pontianak City generate value $21.22 \%$ Because of the value is between $0-25 \%$, the city of Pontianak is considered to have very low financial capacity and have a pattern instructive relations with the central government, which where financial dependence on the central government is still low compared to the regional independence.
\end{abstract}

Keywords: Performance, Regional Finance Capabilities, Regional Autonomy, Regional Financial Independence

\section{PENDAHULUAN}

Otonomi daerah merupakan suatu langkah awal menuju pembangunan ekonomi nasional yang lebih berdaya tumbuh tinggi dengan memberikan kehidupan yang lebih

\footnotetext{
*Korespondensi: Atria Tiffany Widyaningsih, Akademi Perpajakan Panca Bhakti, Jl. Sultan Abdurrahman No. 8 Pontianak, Kalimantan Barat. Email: atria_tiffany@yahoo.co.id
} 
baik bagi masyarakat di daerah. Asas yang menjadi prinsip dasar otonomi adalah otonomi luas, nyata dan bertanggungjawab. Prinsip ini memperhatikan aspek demokrasi, partisipasi, adil dan merata dengan tetap memperhatikan potensi dan keragaman daerah. Berdasarkan asas tersebut, diharapkan otonomi daerah mampu mempercepat terwujudnya kesejahteraan masyarakat daerah. Kesejahteraan masyarakat memang menjadi tujuan utama dari kebijakan otonomi sebagaimana tuntutan pada saat reformasi digulirkan. Tujuan tersebut hanya dapat terwujud dengan adanya pembagian urusan pemerintahan antara pemerintah pusat dengan pemerintah daerah.

Dalam menjamin terselangaranya otonomi daerah yang mantap perlu dilakukan usaha-usaha meningkatkan penerimaan pendapatan asli daerah, baik yang sudah ada maupun dengan menggali sumber dan potensi ekonomi masyarakat. Peningkatan penerimaan pendapatan asli daerah perlu dilakukan dan dikembangkan untuk kesenambungan pembangunan. Dalam rangka upaya peningkatan pendapatan asli daerah perlu diadakan analisis pendapatan asli daerah untuk mendukung otonomi daerah. Pajak daerah perlu dianalisis karena pajak daerah memiliki prospek yang sangat baik untuk dikembangkan. Selain itu pajak daerah harus dikelola secara profesional dan usaha meningkatkan kontribusinya terhadap anggaran pendapatan dan belanja daerah.

Kemampuan keuangan suatu daerah dapat dilihat dari besar kecilnya Pendapatan Asli Daerah (PAD) yang diperoleh daerah yang bersangkutan. Dalam kaitannya dengan pemberian otonomi daerah yang lebih besar kepada daerah. PAD selalu dipandang sebagai salah satu indikator atau kriteria untuk mengukur ketergantungan suatu daerah kepada pusat. Pada prinsipnya semakin besar sumbangan PAD kepada APBD maka akan menunjukkan semakin kecil ketergantungan daerah kepada pusat sebagai konsekuensi pelaksanaan otonomi daerah dari prinsip secara nyata dan bertanggung jawab.

Lembaga pemerintahan melakukan berbagai bentuk pengeluaran guna membiayai kegiatan-kegiatan yang dilakukan di satu sisi, dan di sisi lain lembaga ini harus melakukan berbagai upaya untuk memperoleh penghasilan guna menutupi seluruh biaya tersebut.Dalam melaksanakan aktivitas ekonominya, organisasi atau lembaga pemerintah membutuhkan jasa akuntansi untuk pengawasan dan menghasilkan informasi keuangan yang akan digunakan untuk pengambilan keputusan-keputusan ekonominya. Akan tetapi, karena sifat lembaga pemerintahan berbeda dari sifat perusahaan yang bertujuan mencari laba, maka sifat akuntansi pemerintahan juga berbeda dari sifat akuntansi perusahaan.

Dengan adanya akuntansi pemerintahan maka pemerintah harus mempunyai rencana yang matang untuk suatu tujuan yang dicita-citakan sesuai dengan penerapan akuntansi pemerintahan di Indonesia. Ditetapkannya Undang-undang No. 23 tahun 2014 tentang Pemerintah Daerah serta Undang-undang No. 33 tahun 2004 tentang Perimbangan Keuangan antara pusat dan daerah akan dapat memberikan kewenangan atau otonomi yang luas, nyata dan bertanggung jawab kepada pemerintah daerah secara 
proporsional. Hal ini diwujudkan dengan pengaturan, pembagian dan pemanfaatan sumber daya nasional, serta perimbangan keuangan daerah dan pusat secara demokratis, peran serta masyarakat, pemerataan keadilan, serta memperhatikan potensi dan keragaman daerah, terutama kepada Pemerintah Kabupaten dan Pemerintah Kota.

Tujuan pemberian keuangan dalam penyelenggaraan Otonomi Daerah adalah guna meningkatkan kesejahteraan rakyat, pemerataan dan keadilan sosial. Menurut Undang-Undang No. 23 tahun 2014 pasal 1 ayat 5 Otonomi Daerah adalah hak, wewenang dan kewajiban daerah otonom untuk mengatur dan mengurus sendiri urusan pemerintah dan kepentingan masyarakat setempat sesuai dengan peraturan perundang-undangan. Berkaitan dengan hal tersebut peranan pemerintah daerah sangat menentukan berhasil tidaknya menciptakan kemandirian yang selalu didambakan Pemerintah Daerah.

Terlepas dari perdebatan mengenai ketidaksiapan daerah di berbagai bidang untuk melaksanakan kedua Undang-undang tersebut, otonomi daerah diyakini merupakan jalan terbaik dalam rangka mendorong pembangunan daerah. Menggantikan sistem pembangunan terpusat yang oleh beberapa pihak dianggap sebagai penyebab lambannya pembangunan di daerah dan semakin besarnya ketimpangan antar daerah.

Berkaitan dengan hal tersebut, Halim (2004) menjelaskan bahwa ciri utama suatu daerah yang mampu melaksanakan otonomi dan desetralisasi, yaitu:

1. Kemampuan keuangan daerah, artinya daerah harus memiliki kewenangan dan kemampuan untuk menggali sumber-sumber keuangan, mengelola dan menggunakan keuangan sendiri yang cukup memadai untuk membiayai penyelenggaraan pemerintahannya. Artinya daerah harus mampu mengelola keuangan daerahnya baik penerimaan maupun pengeluarannya, dimana penerimaan yang diperoleh daerah kemudian dialokasikan sebagai pembiayaan belanja daerahnya.

2. Ketergantungan kepada bantuan pusat harus seminimal mungkin, agar pendapatan asli daerah (PAD) dapat menjadi bagian sumber keuangan terbesar sehingga peranan pemerintah daerah menjadi lebih besar Dwirandra (2006) dalam Rusydi (2011). Jadi, PAD harus menjadi basis utama penerimaan daerah dibandingkan dengan DAU agar daerah mampu melaksanakan otonomi dan desentralisasi seutuhnya.

Kinerja dan kemampuan keuangan daerah merupakan salah satu ukuran yang dapat digunakan untuk melihat kemampuan daerah dalam menjalankan otonomi daerah (Halim, 2004). Struktur keuangan daerah tercermin dalam 2 sisi, yaitu sisi penerimaan dan sisi pengeluaran. Sisi penerimaan adalah PAD, dana perimbangan, dan pendapatan lain-lain yang sah sedangkan sisi pengeluaran adalah belanja daerah. Dana perimbangan dan PAD merupakan sumber penerimaan daerah yang memberikan kontribusi besar kepada anggaran penerimaan. 
Dengan adanya Otonomi Daerah, kewenangan yang dimiliki oleh pemerintah daerah akan semakin besar sehingga tanggung jawab yang diembannya akan bertambah banyak. Implikasi dari adanya kewenangan urusan pemerintahan yang begitu luas yang diberikan kepada daerah dalam rangka otonomi daerah dapat menjadi suatu berkah bagi daerah. Namun disisi lain bertambahnya kewenangan daerah tersebut juga merupakan beban yang menuntut kesiapan daerah untuk pelaksanaannya, karena semakin besar urusan pemerintah yang menjadi tanggung jawab pemerintah daerah.

Oleh karena itu, ada beberapa aspek yang harus dipersiapkan antara lain sumber daya manusia, sumber daya keuangan, sarana dan pra sarana daerah. Aspek keuangan merupakan salah satu dasar kriteria untuk dapat mengetahui secara nyata kemampuan daerah dalam mengurus rumah tangganya sendiri. Kemampuan daerah yang dimaksud adalah sampai sejauh mana daerah dapat menggali sumber-sumber keuangan sendiri guna membiayai kebutuhan keuangan daerah tanpa harus menggantungkan diri pada bantuan dan subsidi dari pemerintah pusat. Kemampuan pemerintah daerah dalam mengelola keuangan tercermin dalam Anggaran Pendapatan Belanja Daerah (APBD) yang menggambarkan kemampuan pemerintah daerah dalam membiayai kegiatan pelaksanaan tugas pembangunan, serta pemerataan dan keadilan dengan mengembangkan seluruh potensi yang dimiliki oleh masing-masing daerah.

Kemampuan keuangan suatu daerah dapat dilihat dari besar kecilnya Pendapatan Asli Daerah (PAD) yang diperoleh daerah yang bersangkutan. Dalam kaitannya dengan pemberian otonomi daerah yang lebih besar kepada daerah. PAD selalu dipandang sebagai salah satu indikator atau kriteria untuk mengukur ketergantungan suatu daerah kepada pusat. Pada prinsipnya semakin besar sumbangan PAD kepada APBD maka akan menunjukkan semakin kecil ketergantungan daerah kepada pusat sebagai konsekuensi pelaksanaan otonomi daerah dari prinsip secara nyata dan bertanggung jawab.

Dalam rangka mewujudkan pertanggung jawaban keuangan melalui perhitungan tersebut, perhitungan anggaran yang telah ditetapkan oleh pemerintah Kota Pontianak sejak Tahun Anggaran 2011 sampai sampai tahun 2014, selalu menunjukkan adanya Kenaikan dapat dilihat pada Tabel 1.

Berdasarkan Tabel 1 tersebut pada tahun 2011 realisasi pendapatan sebesar Rp. 765.700.088.194,17 dengan target sebesar Rp. 801.516.577.716,66 atau 95,53\% sedangkan realisasi belanja sebesar Rp. 752.867.063.169,12 dengan target sebesar Rp. 826.258.381.426,96 atau 91,12\% pada tahun 2012 realisasi pendapatan sebesar Rp. 920.727.224.217,34 dengan target sebesar Rp. 935.858.780.555,25 atau 98,38\% sedangkan realisasi belanja sebesar Rp. 891.672.005.596,75 dengan target sebesar Rp. 965.283.440.932,80 atau 92,37\%. 
Tabel 1. Anggaran dan Realisasi Belanja Pemerintah Kota Pontianak Tahun Anggaran 2011-2014

\begin{tabular}{lrrrrrr}
\hline Tahun & \multicolumn{3}{c}{ Pendapatan } & \multicolumn{3}{c}{ Belanja } \\
\cline { 2 - 7 } & \multicolumn{1}{c}{ Target } & \multicolumn{1}{c}{ Realisasi } & \multicolumn{1}{c}{ (\%) } & \multicolumn{1}{c}{ Target } & \multicolumn{1}{c}{ Realisasi } & $(\boldsymbol{\%})$ \\
\hline 2011 & $801.516 .577 .716,66$ & $765.700 .088 .194,17$ & $95,53 \%$ & $826.258 .381 .426,96$ & $752.867 .063 .169,12$ & 91,12 \\
2012 & $935.858 .780 .555,25$ & $920.727 .224 .217,34$ & $98,38 \%$ & $965.283 .440 .932,80$ & $891.672 .005 .596,75$ & 92,37 \\
2013 & $1.077 .049 .414 .461,92$ & $1.076 .345 .061 .831,18$ & $99,93 \%$ & $1.115 .955 .094 .821,26$ & $1.006 .492 .631 .240,15$ & 90,19 \\
2014 & $1.296 .146 .443 .040,64$ & $1.247 .089 .546 .932,33$ & $96,22 \%$ & $1.396 .834 .104 .682,67$ & $1.309 .158 .772 .458,49$ & 93,72 \\
\hline
\end{tabular}

Berdasarkan kondisi tersebut, maka yang menjadi permasalahan dalam penelitian ini adalah: kemampuan keuangan daerah dalam pelaksanaan otonomi daerah khususnya pada tahun 2011-2014, jika ditinjau dari Indikator Derajat Disentralisasi Fiskal (DDF), Derajat Otonomi Fiskal (DOF), Kapasitas Fiskal, Kebutuhan Fiskal, Upaya/Posisi Fiskal Rasio Efektifitas Pendapatan asli Daerah (PAD) serta Indikator Kinerja Pajak dan Retibusi Daerah di Kota Pontianak. Dan akan dibahas pula mengenai tingkat kemandirian keuangan daerah pada tahun 2011-2014 dalam membiayai penyelenggara otonomi daerah yang diukur dengan Rasio Kemandirian Keuangan Daerah dan Pola Hubungannya di Kota Pontianak.

\section{TINJAUAN PUSTAKA}

Dalam penelitian ini, indikator yang digunakan sebagai bahan analisis mengenai kemampuan keuangan daerah Kota Pontianak adalah Derajat Desentralisasi Fiskal (DDF), Derajat Otonomi Fiskal (DOF), Kapasitas Fiskal, Kebutuhan Fiskal, Upaya/ Posisi Fiskal, Rasio Efektifitas Pendapatan Asli serta Indikator Kinerja Pajak dan Retribusi Daerah. Data yang digunakan untuk mengukur indikator DDF adalah data pendapatan daerah yang meliputi PAD, Sumbangan dan Bantuan serta Bagi Hasil Pajak dan Bukan Pajak. Selain untuk mengukur indikator DDF, data PAD juga digunakan dalam pengukuran indikator DOF, Rasio Efektivitas serta Indikator Kinerja Pajak dan Retribusi. Untuk indikator Upaya Fiskal digunakan data PAD dan PDRB. Sedangkan data jumlah penduduk dan PDRB digunakan untuk mengukur indikator Kapasitas Fiskal, serta data belanja daerah untuk pengukuran indikator Kebutuhan Fiskal.

\subsection{Otonomi Daerah}

Secara etimologis, kata otonomi berasal dari bahasa latin: auto berarti sendiri dan nomein berarti peraturan, atau undang-undang. Maka autonom berarti mengatur sendiri, atau memerintah sendiri, atau dalam arti luas adalah hak untuk mengatur dan 
mengurus rumah tangga daerah sendiri (Adisubrata, 2003). Menurut pasal 1 UU No. 23 Tahun 2014, Otonomi Daerah adalah hak, wewenang, dan kewajiban daerah otonom untuk mengatur dan mengurus sendiri urusan pemerintahan dan kepentingan masyarakat setempat sesuai dengan peraturan perundang-undangan.

Sedangkan yang dimaksud dengan Daerah Otonomi adalah kesatuan masyarakat hukum yang mempunyai batas-batas wilayah yang berwenang mengatur dan mengurus urusan pemerintahan dan kepentingan masyarakat setempat menurut prakarsa sendiri berdasarkan aspirasi masyarakat dalam sistem Negara Kesatuan Republik Indonesia.

Kaho (1998) dalam Safi'i (2007) mengemukakan bahwa yang dimaksud dengan Otonomi Daerah adalah hak dan wewenang untuk mengatur dan mengurus rumah tangganya sendiri. Urusan rumah tangga sendiri ialah urusan yang lahir atas adanya prakarsa daerah dan dibiayai dengan pendapatan daerah yang bersangkutan. Sedangkan menurut Safrudin dalam Adisubrata (2003), istilah otonomi mempunyai makna kebebasan atas kemandirian tetapi bukan kemerdekaan, artinya kebebasan yang terbatas, kebebasan yang harus dipertanggung jawabkan kepada pemerintah yang lebih tinggi (pemerintah pusat).

\subsection{Keuangan Daerah}

Keuangan Daerah adalah semua hak dan kewajiban daerah dalam rangka penyelenggaraan pemerintahan daerah yang 16dapat dinilai dengan uang termasuk di dalamnya segala bentuk kekayaan yang berhubungan dengan hak dan kewajiban daerah tersebut, dalam kerangka Anggaran Pendapatan dan Belanja Daerah (Pasal 1 ayat 5 PP No. 58 Tahun 2005 dalam Halim, 2004).

Dari pengertian diatas, dapat dilihat bahwa dalam keuangan daerah terdapat dua unsur penting yaitu.

a. Semua hak dimaksudkan sebagai hak untuk memungut pajak daerah, retribusi daerah dan/atau penerimaan dan sumbersumber lain sesuai ketentuan yang berlaku merupakan penerimaan daerah sehingga menambah kekayaan daerah;

b. Kewajiban daerah dapat berupa kewajiban untuk membayar atau sehubungan adanya tagihan kepada daerah dalam rangka pembiayaan rumah tangga daerah serta pelaksanaan tugas umum dan tugas pembangunan oleh daerah yang bersangkutan.

Berdasarkan pasal 66 UU No. 33/2004, asas umum pengelolaan keuangan daerah adalah sebagai berikut:

1. Keuangan daerah dikelola secara tertib, taat pada peraturan perundang- undangan, efisien, ekonomis, efektif, transparan, dan bertanggungjawab dengan memperhatikan keadilan, kepatuhan, dan manfaat untuk masyarakat.

2. APBD, perubahan APBD, dan pertanggungjawaban pelaksanaan APBD setiap tahun 
ditetapkan dengan Peraturan Daerah

3. APBD mempunyai fungsi otorisasi, perencanaan, pengawasan, alokasi, dan distribusi.

4. Semua penerimaan dan pengeluaran daerah dalam tahun anggaran yang bersangkutan harus dimasukkan dalam APBD.

5. Surplus APBD dapat digunakan untuk membiayai pengeluaran daerah tahun anggaran berikutnya.

6. Penggunaan surplus APBD dimaksudkan untuk membentuk dana cadangan atau penyertaan dalam perusahaan daerah harus memperoleh persetujuan terlebih dahulu dari DPRD.

\subsection{Manajemen Keuangan Daerah}

Guna mewujudkan keuangan daerah yang transparan dan akuntabel, dibutuhkan pengelolaan dengan suatu sistem manajemen keuangan yang jelas dan berdaya guna. Manajemen merupakan proses perencanaan, pengorganisasian, pengarahan, pengkoordinasian, dan pengawasan usaha-usaha para anggota organisasi dan penggunaan sumber daya organisasi lainnya agar mencapai tujuan yang telah ditetapkan. Dari pengertian tersebut, jelas bahwa manjemen mempunyai empat fungsi dasar, yaitu perencanaan, pengorganisasian, kepemimpinan, dan pengendalian.

Konsep dasar dari manajemen tersebut dapat diaplikasikan dalam berbagai jenis organisasi, termasuk lingkungan organisasi sektor publik tidak terkecuali dalam pengelolaan keuangan daerah.

Beberapa prinsip penting manajemen keuangan daerah yaitu:

a. Taat pada peraturan perundang-undangan, dengan maksud bahwa pengelolaan keuangan daerah harus berpedoman pada peraturan perundang- undangan.

b. Efektif merupakan pencapaian hasil program dengan target yang telah ditetapkan, yaitu dengan cara membandingkan keluaran dengan hasil.

c. Efisien merupakan pencapaian keluaran yang maksimum dengan masukan tertentu atau penggunaan masukan terendah untuk mencapai keluaran tertentu.

d. Ekonomis merupakan pemerolehan masukan dengan kualitas dan kuantitas tertentu pada tingkat harga terendah.

e. Transparan merupakan prinsip keterbukaan yang memungkinkan masyarakat untuk mengetahui dan mendapatkan akses informasi seluas- luasnya tentang keuangan daerah.

f. Bertanggungjawab merupakan wujud dari kewajiban seseorang untuk mempertanggungjawabkan pengelolaan dan pengendalian sumber daya dan pelaksanaan kebijakan yang dipercayakan kepadanya dalam rangka pencapaian tujuan 
yang telah ditetapkan.

g. Keadilan adalah keseimbangan distribusi kewenangan dan pendanaannya dan/atau keseimbangan distribusi hak dan kewajiban berdasarkan pertimbangan yang objektif.

h. Kepatutan adalah tindakan atau suatau sikap yang dilakukan dengan wajar dan proporsional.

i. Manfaat maksudnya keuangan daerah diutamakan untuk pemenuhan kebutuhan masyarakat.

\subsection{Anggaran Pendapatan dan Belanja Daerah (APBD)}

Anggaran Pendapatan dan Belanja Daerah (APBD) adalah suatu rencana keuangan tahunan daerah yang ditetapkan berdasarkan peraturan daerah tentang APBD yang disetujui oleh DPRD. Menurut pasal 16 Permendagri No. 13/2006 (Yuwono, 2008), APBD memiliki fungsi sebagai berikut.

1. Otorisasi; anggaran daerah menjadi dasar untuk melaksanakan pendapatan dan belanja pada tahun yang bersangkutan.

2. Perencanaan; anggaran daerah menjadi pedoman bagi manajemen dalam merencanakan kegiatan pada tahun yang bersangkutan.

3. Pengawasan; anggaran daerah menjadi pedoman untuk menilai apakah kegiatan penyelenggaraan pemerintah daerah sudah sesuai dengan ketentuan yang telah ditetapkan.

4. Alokasi; anggaran daerah harus diarahkan untuk menciptakan lapangan kerja/mengurangi pengangguran dan pemborosan sumber daya serta meningkatkan efisiensi dan efektifitas perekonomian.

5. Distribusi; kebijakan anggaran daerah harus memperhatikan rasa keadilandan kepatutan.

6. Stabilisasi; anggaran pemerintah daerah menjadi alat untuk memelihara dan mengupayakan keseimbangan fundamental perekonomian daerah.

Yuwono (2008) mengemukakan, jika keuangan daerah (APBD) dapat dikatakan sebagai jantung pengelolaan lembaga pemerintahan daerah, maka pengelolaan APBD merupakan denyut nadi yang merefleksikan dinamika keuangan daerah sekaligus merupakan bagian integral dari sistem keuangan Negara sebagaimana diatur dalam UU No. 17/2003. Dalam UU No. 23/2014 juga disebutkan bahwa pengelolaan APBD merupakan bagian tak terpisahkan dari sistem pengelolaan pemerintah daerah. Mengingat bahwa salah satu sumber pendanaan APBD berasal dari APBN, maka proses penyusunan APBD diatur dalam UU No. 33/2004 tentang Perimbangan Keuangan antara Pemerintah Pusat dan Daerah yang penjabarannya diatur dalam PP No. 58/2005 tentang Pengelolaan 
Keuangan Daerah dan PP terkait lainnya. 2007)

Arti penting anggaran daerah dapat dilihat dari aspek-aspek berikut ini. (Halim,

1. Anggaran merupakan alat bagi pemerintah daerah untuk mengarahkan dan menjamin kesinambungan pembangunan serta meningkatkan kualitas hidup masyarakat.

2. Anggaran diperlukan karena adanya kebutuhan dan keinginan masyarakat yang tak terbatas dan terus berkembang sedangkan sumber daya yang ada terbatas. Anggaran diperlukan karena adanya masalah keterbatasan sumber daya (scarcity of resources), pilihan (choice) dan trade offs.

Berdasarkan Permendagri No. 13 Tahun 2006 tentang Pedoman Pengelolaan Keuangan Daerah, disebutkan bahwa struktur APBD terdiri atas pendapatan, belanja, dan pembiayaan.

1. Pendapatan Daerah

Pendapatan daerah adalah hak pemerintah daerah yang diakui sebagai penambah nilai kekayaan bersih dalam periode tahun bersangkutan (UU No. 33/2004 pasal 1). Pendapatan daerah dalam struktur APBD dikelompokkan atas Pendapatan Asli Daerah (PAD), dana perimbangan, dan lain-lain pendapatan yang sah.

\section{Belanja Daerah}

Belanja daerah adalah semua kewajiban daerah yang diakui sebagai pengurang nilai kekayaan bersih dalam periode tahun anggaran yang bersangkutan. (UU No. 33/2004 pasal 1). Belanja daerah dipergunakan dalam rangka mendanai pelaksanaan urusan pemerintahan yang menjadi kewenangan propinsi/kabupaten/kota yang terdiri atas urusan wajib, urusan pilihan, dan urusan yang penanganannya dalam bagian atau bidang tertentu yang dapat dilaksanakan bersama pemerintah pusat dan pemerintah daerah atau antar pemerintah daerah yang ditetapkan dengan ketentuan perundangundangan.

Dalam penyelenggaraan belanja, urusan wajib diprioritaskan untuk melindungi dan meningkatkan kuaitas kehidupan masyarakat sebagai upaya pemenuhan kewajiban daerah yang diwujudkan dalam bentuk peningkatan pelayanan dasar, pendidikan, kesehatan, fasilitas sosial, dan fasilitas umum yang layak serta mengembangkan sistem jaminan sosial. Peningkatan kualitas kehidupan masyarakat tersebut diwujudkan melalui prestasi kinerja dalam pencapaian standar minimal sesuai peraturan perundang-undangan.

3. Pembiayaan Daerah

Pembiayaan adalah setiap penerimaan yang perlu dibiayai kembali dan/atau pengeluaran yang akan diterima kembali, baik pada tahun anggaran yang 
bersangkutan maupun tahun-tahun anggaran berikutnya (UU No. 33/2004 pasal 1). Pembiayaan daerah bersumber dari: sisa lebih perhitungan anggaran tahun lalu, transfer dari dana cadangan, hasil penjualan kekayaan daerah yang dipisahkan, dan pinjaman daerah.

\subsection{Laporan Keuangan Daerah}

\section{a. Laporan Laba Rugi (Income Stetement)}

Laporan laba-rugi adalah laporan keuangan yang melaporkan mengenai aktifitas operasional perusahaan dengan menghitung pendapatan dan beban- beban selama satu periode yang kemudian dapat ditentukan laporan laba- ruginya. Ada dua pendekatan sebagai dasar menggolongkan, serta mengikhtisiarkan transaksi-transaksi yang terjadi dalam perusahaan. Kedua pendekatan itu adalah.

1. Dasar Tunai (cash basis) yaitu; suatu system yang mengakui penghasilan pada saat uang tunai diterima dan mengakui beban pada saat mengeluarkan uang tunai. Metode ini cocok untuk perusahaan dengan skala kecil, karena metode ini kurang tepat untuk mengakui laba atau rugi laba pada periode tertentu.

2. Dasar waktu (akrual basis) yaitu suatu sistem yang mengakui pendapatan pada saat terjadinya transaksi, walaupun sudah atau belum menerima uang tunai mengakui beban pada saat terjadinya transaksi walaupun sudah atau belum mengeluarkan uang tunai.

Metode dasar waktu (akrual basis) ini sangat tepat untuk perusahaan yang melakukan transaksi secara kredit, karena laporan laba-rugi akan mencerminkan kondisi yang benar selama satu periode tertentu. Dalam laporan laba-rugi, terdapat tiga rekening (akun) yang perlu dipahami secara jelas yaitu; pendapatan adalah penghasilan yang timbul dari pelaksanaan aktivitas perusahaan yan biasa (reguler) dan dikenal sebutan yang berbeda-beda, seperti,penjualan, penghasilan jasa (fee), bunga, deviden, royalti dan sewa. Beban adalah pengorbanan yang timbul dalam pelaksanaan aktivitas yan biasa (reguler), seperti beban pokok penjualan, beban gaji, beban sewa, beban penysutan aset tetap, beba asuransi, beban pajak, beban kerugian piutang, beban perlengkapan. Laba atau Rugi terjadi bila pendapatan lebih besar dari beban-beban yang terjadi, sebaliknya rugi terjadi bila pendapatan lebih kecil dari pada beban-beban yang terjadi.

\section{b. Laporan Neraca (Balance Sheet)}

Yaitu laporan keuangan yang menunjukkan posisi aset, kewajiban dan ekuitas pada periode tertentu. Data untuk menyusun laporan neraca diambil dari neraca lajur. Isi neraca secara garis besar adalah sebagai berikut.

1. Kelompok Aset: 

a. Aset Lancar
b. Investasi jangka panjang
c. Aset tetap- Aset yang tidak berwujud
d. Aset lain-lain

2. Kelompok Kewajiban
a. Kewajiban lancer
b. Kewajiban jangka panjang
c. Kewajiban lain-lain

3. Kelompok Ekuitas
a. Modal saham
b. Agio/disagio saham
c. Cadangan-cadangan
d. Saldo laba

Aset, adalah kekayaan atau sumber-sumber ekonomi yang dimiliki perusahaan dan diharapkan akan member manfaat dimasa yang akan dating. Asset terdiri atas sebagai berikut.

a. Aset Lancar (current assets) adalah uang tunai dan saldo rekening giro di Bank serta kekayaan-kekayaan lain yang dapat diharapkan bias dicairkan menjadi uang tunai atau rekening giro Bank, atau dijual maupun dipakai habis dalam operasi perusahaan, dalam jangka pendek ( satu tahun atau satu siklus operasi normal perusahaan). Yang termasuk asset lancer: Kas (saldo uang tunai pada tanggal neraca), Bank ( saldo rekening giro bank pada tanggal neraca), Surat berharga jangka pendek, piutang, persediaan (barang berwujud yang tersedia untuk dijual, di produksi atau masih dalam proses), beban dibayar dimuka.

b. Investasi jangka panjang (long-term investments) Terdiri dari aset berjangka panjang (tidak untuk dicairkan dalam waktut satu tahun atau kurang) yang diinvestasikan bukan untuk menunjang kegiatan operasi pokok perusahaan. Misalnya: penyertaan pada perusahaan dalam bentuk saham, obligasi atau surat berharga, dana untuk tujuan-tujuan khusus (dana untuk pelunasan hutang jangka panjang), tanah yang dipakai untuk lokasi usaha.

c. Aset Tetap (fixed assets) Aset berwujud yang digunakan untuk operasi normal perusahaan, mempunyai umur ekonomis lebih dari satu tahun atau satu siklus operasi normal dan tidak dimaksudkan untuk dijual sebagai barang dagangan. Misalnya: tanah untuk lokasi baru, gedung, mesin-mesin dan peralatan produksi, peralatan kantor, kendaraan. 
d. Aset Tak Berwujud (intangible assets) Terdiri hak-hak istemewa atau posisi yang menguntungkan perusahaan dalam memperoleh pendapatan, missal: hak paten, hak cipta, franchise, merk dagang, atau logo dan goodwill.

e. Aset Lain-lain (other assets) Untuk menampung asset yang tidak bisa digolongkan sebagai asset lancer, investasi jangka panjang, aset tetap dan tetap tak berwujud. Misalnya; mesin yang dipakai dalam operasi.

Kewajiban dapat digolongkan menjadi:

1. Kewajiban Lancar (current liabilities) Kewajiban lancar meliputi kewajiban yang harus diselesaikan dalam jangka pendek atau jangka satu tahun atau jangka satu siklus operasi normal perusahaan. Misalnya: hutang usaha, beban yang harus masih dibayar, pendapatan yang diterima dimuka, utang pajak, utang bunga.

2. Kewajiban Jangka Panjang (long-term debts) Kewajiban jangka panjang adalah kewajiban yang jatuh temponya melebihi satu periode akuntansi atau lebih dari satu tahun. Misalnya: utang hipotik, utang obligasi.

3. Kewajiban Lain-lain (other liabilities) Adalah kewajiban yang tidak bisa digolongkan ke kewajiban lancar dan kewajiban jangka panjang.

4. Ekuitas

Menunjukan hak milik para pemilik asset perusahaan yang diukur atau ditentukan besarnya dengan menghitung selisih antara asset dan kewajiban.

\section{c. Laporan Perubahan Ekuitas}

Laporan keuangan yang menunjukkan perubahan ekuitas selama satu periode. Laporan ekuitas terdiri dari saldo awal modal pada neraca saldo setelah disesuaikan ditambah laba bersih selama satu periode dikurangi dengan pengambilan prive. Komponen laporan perubahan ekuitas adalah sebagai berikut.

1. Modal awal diperoleh dari investasi awal ataupun penambahan nilai investasi.

2. Laba atau Rugi Laba perusahaan akan menambah modal perusahaan, sedangkan rugi akan mengurangi modal perusahaan.

3. Penarikan (prive) Apabila sebagian laba diambil oleh pemilik untuk kepentingannya sendiri diluar kepentingan perusahaan, maka kejadian ini akan mengurangi modal pemilik. Jika perusahaan perseorangan atau firma maka penarikan disebut prive dan jika berbentuk perseroan (PT) disebut Dividen. Apabila laba besar dari pada penarikan maka akan ada kenaikan modal, sebaliknya jika laba lebih kecil dari penarikan makan akan terjadi penurunan modal.

4. Modal Akhir adalah saldo modal awal ditambah laba rugi dikurangi penarikan. 


\section{d. Laporan Arus Kas}

Laporan arus kas menunjukkan sumber dan penggunaan kas sselama satu periode sehingga saldo kas Nampak seperti neraca, laporan arus kas membutuhkan data/informasi dari neraca periode sbelumnya dan periode yang bersangkutan dan laporan laba rugi pada periode yang bersangkutan.

\subsection{Kinerja Keuangan Daerah}

Salah satu aspek dari pemerintah yang harus diatur adalah masalah pengelolaan keuangan daerah dan anggaran daerah. Dalam upaya pemberdayaan pemerintah daerah, maka perspektif perubahan yang diinginkan dalam pengelolaan keuangan daerah di masa otonomi daerah dan anggaran daerah adalah.

a. Pengelolaan keuangan daerah harus bertumpu pada kempentingan publik, hal ini tidak saja terlihat dari besarnya porsi penganggaran untuk kepentingan publik, tetapi pada besarnya partispasi masyarakat dalam perencanaan pelaksanaan dan pengawasan keuangan daerah;

b. Kejelasan tentang misi pengelolaan keuangan daerah dan anggaran daerah pada khususnya;

c. Desentralisasi pengelolaan keuangan dan kejelasan peran serta partispasi yang terkait dengan pengelolaan anggaran seperti DPRD, Kepala Daerah, Sekretariat daerah dan perangkat daerah lainnnya;

d. Kerangka hukum dan administrasi bagi pembiayaan, investasi dan pengelolaan uang daerah berdasarkan kaidah mekanisme pasar;

e. Kejelasan aturan tentang pengeluaran operasional lain-lain yang tidak jelas akuntabilitas;

f. Prinsip anggaran dan kejelasan larangan pengaturan alokasi anggaran di luar yang diterapkan dalam strategi dan prioritas APBD.

Ciri utama yang menunjukkan suatu daerah otonom mampu berotonomi adalah terletak pada kemampuan keuangan daerah untuk membiayai penyelenggaraan pemerintahan daerahnya dengan tingkat ketergantungan kepada pemerintah pusat yang mempunyai proporsi semakin kecil. Oleh karena itu, diharapkan PAD dapat menjadi bagian terbesar dalam memobilisasi dana penyelenggaraan pemerintahan daerah.

\section{METODE PENELITIAN}

Penelitian dilaksanakan di Kantor BPKAD Kota Pontianak, dengan metode deskriptif kuantitatif yakni analisis yang menggunakan data yang diukur dalam suatu skala numerik/angka. (Kuncoro, 2003) Analisis ini bertujuan untuk mengetahui tingkat 
kemampuan keuangan daerah, tingkat kemandirian daerah serta kesiapan pemerintah daerah Kota Pontianak dalam penyelenggaraan otonomi daerah.

Dalam pengumpulan data adapun alat pengumpul data yang digunakan adalah sebagai berikut:

1. Wawancara

Wawancara adalah mendapatkan informasi dengan cara bertanya atau bertatap muka secara langsung kepada pihak yang berkaitan tentang keuangan daerah serta otonomi daerah Kota Pontianak yaitu dengan Bagian Akuntansi di kantor BPKAD Kota Pontianak. Wawancara dilakukan secara terstruktur dengan menggunakan Pedoman Wawancara.

2. Daftar Observasi (pengamatan)

Dalam penelitian ini penulis mengobservasi langsung atau tidak langsung masalah tentang bagaimana kemampuan keuangan daerah Kota Pontianak dan apa saja yang menjadi masalah dalam pelaksanaan otonomi daerah Kota Pontianak.

3. Dokumentasi

Adalah catatan yang sudah berlalu yang menyediakan dokemen- dokumen, gambar, bukti-bukti, buku, undang-undang, peraturan, dan lain-lain. Dalam penelitian ini penulis mendapatkan data kuantitatif dalam bentuk hardcopy maupun softcopy.

\section{TEMUAN DAN PEMBAHASAN}

\subsection{Analisis Kualitatif}

\subsubsection{Pertumbuhan APBD}

Pada dasarnya Anggaran Pendapatan dan Belanja Daerah (APBD) merupakan rencana keuangan tahunan Pemerintahan Daerah yang dibahas dan disetujui oleh Pemerintah Daerah dan DPRD, dan ditetapkan dengan Peraturan Daerah. APBD dapat menjadi sarana bagi pihak tertentu untuk melihat/mengetahui kemampuan keuangan daerah, baik dari sisi pendapatan maupun dari sisi belanja. Tabel berikut merupakan gambaran perkembangan penerimaan APBD Kota Pontianak tahun 2011-2014. Untuk mengatahui penerimaan APBD Kota Pontianak dengan menggunakan rumus (pendapatan daerah - belanja daerah) apakah menjadi surplus atau defisit.

Tabel 2. Penerimaan APBD Kota Pontianak Tahun 2011-2014

\begin{tabular}{cccc}
\hline Tahun & Pendapatan Daerah & Belanja Daerah & Surplus/Defisit \\
\hline 2011 & $765.700 .088 .194,17$ & $752.867 .063 .169,12$ & $12.833 .025 .025,05$ \\
2012 & $920.727 .224 .217,34$ & $891.672 .005 .596,75$ & $29.055 .218 .620,59$ \\
2013 & $1.076 .345 .061 .831,18$ & $1.006 .492 .631 .240,15$ & $69.852 .430 .591,03$
\end{tabular}


Dari Tabel 2 dapat dilihat dari tahun ke tahun pendapatan Kota Pontianak terus mengalami peningkatan. Peningkatan pendapatan ini terkadang juga diimbangi dengan meningkatnya jumlah belanja daerah sehingga surplus/defisit daerah juga berfluktuasi. Seperti pada tahun 2014 terlihat terjadi defisit sebesar -62.069.225.526,84 defisit ini disebabkan adanya kendala dalam melaksanakan program pembangunan, jika APBD yang defisit kebijakan yang diambil yaitu,memanfaatkan anggaran yang berasal dari sisa lebih perhitungan anggaran tahun lalu atau menjual aset kekayaan daerah, melakukan pinjaman, dan menjual obligasi.

\subsubsection{Kontribusi PAD terhadap APBD}

Pendapatan Asli Daerah (PAD) merupakan cerminan dari potensi ekonomi daerah. Salah satu cara untuk mengetahui tingkat kemampuan suatu daerah adalah dengan melihat besarnya kontribusi PAD terhadap total penerimaan APBD. Untuk mencari kontribusi PAD terhadap APBD dengan menggunakan rumus: $\mathrm{PAD}=$ APBD x $100 \%$.

Tabel 3. Kontribusi PAD terhadap APBD Kota Pontianak Tahun 2011-2014

\begin{tabular}{crcc}
\hline Tahun & PAD $($ Rp) & APBD (Rp) & Kontribusi PAD (\%) \\
\hline 2011 & $87.368 .264 .213,70$ & $765.700 .088 .194,17$ & 11,41 \\
2012 & $151.139 .421 .187,94$ & $920.727 .224 .217,34$ & 16,41 \\
2013 & $208.628 .660 .840,82$ & $1.076 .345 .061 .831,18$ & 19,38 \\
2014 & $265.271 .762 .170,33$ & $1.247 .089 .546 .932,33$ & 21,27 \\
\hline \multicolumn{5}{r}{ Rata-rata } & 17,11 \\
\hline
\end{tabular}

Hasil perhitungan Tabel 3 tersebut memperlihatkan bahwa dalam kurun waktu tahun 2011-2014 kontribusi PAD terhadap APBD terus mengalami peningkatan. Kontribusi PAD terhadap APBD yang terendah di tahun 2011 dengan nilai sebesar 11,41\%. Jika dilihat secara rata-rata, kontribusi PAD terhadap APBD ini bernilai $17,11 \%$. Hal tersebut mengindikasikan peranan yang masih sangat kecil dan Pemerintah Daerah Kota Pontianak masih perlu mengoptimalkan lagi penggalian potensi- potensi daerahnya yang potensial bagi pemasukan PAD.

\subsection{Analisis Kuantitatif}

\subsubsection{Derajat Desentralisasi Fiskal (DDF)}

Penghitungan Derajat Desentralisasi Fiskal (DDF) dapat dilakukan dengan menggunakan tiga (3) formula, yakni rasio antara Pendapatan Asli Daerah (PAD) dengan 
Total Pendapatan Daerah (TPD), rasio Bagi Hasil Pajak dan Bukan Pajak (BHPBP) dengan TPD dan rasio Sumbangan dan Bantuan Daerah (SBD) dengan TPD. Jika hasil rasio antara PAD dengan TPD maupun BHPBP dengan TPD lebih dari 50\% maka kemampuan keuangan daerah dapat dikatakan semakin baik/mandiri.

Sebaliknya jika nilainya kurang dari 50\% maka kemampuan keuangan daerah dikatakan belum mandiri. Sedangkan untuk rasio antara SBD dengan TPD, jika nilainya lebih dari 50\% berarti tingkat ketergantungan Pemerintah Daerah terhadap Pemerintah Pusat semakin tinggi. Tetapi jika kurang dari 50\% maka tingkat ketergantungan finansial terhadap Pemerintah Pusat berkurang. Untuk mencari derajat desentralisasi fiskal dapat menggunakan rumus DDF1 = PAD : TPD, DDF2 = BHPBP : TPD dan DDF3 = SBD : TPD.

Tabel 4. Data Pendapatan PAD, BHPBP dan SBD Tahun 2011-2014

\begin{tabular}{lrrrr}
\hline Tahun & \multicolumn{1}{c}{ PAD } & BHPBP & \multicolumn{1}{c}{ SBD } & \multicolumn{1}{c}{ TPD } \\
\hline $\mathbf{2 0 1 1}$ & $96.595 .549 .904,85$ & $499.166 .051 .965,00$ & $179.165 .772 .015,47$ & $765.700 .088 .194,17$ \\
$\mathbf{2 0 1 2}$ & $151.139 .421 .187,94$ & $542.387 .713 .353,00$ & $227.200 .089 .676,40$ & $920.727 .224 .217,34$ \\
$\mathbf{2 0 1 3}$ & $208.628 .660 .840,82$ & $659.548 .774 .706,00$ & $208.167 .626 .284,36$ & $1.076 .345 .061 .831,18$ \\
$\mathbf{2 0 1 4}$ & $256.271 .762 .170,33$ & $699.877 .420,402,00$ & $281.940 .364 .360,00$ & $1.247 .089 .546 .932,33$ \\
\hline
\end{tabular}

Dalam pendapatan PAD, BHPBP dan SBD Kota Pontianak dari tahun ke tahun mengalami peningkatan terutama pada PAD dan BHPBP tiap tahun meningkat, sedangkan SBD Kota Pontianak pada tahun 2013 sedikit menurun tetapi pada tahun 2014 mengalami kenaikan lagi, dari jumlah 208.167.626.284,36 menjadi 281.940.364.360,00. Dalam hal ini Kota Pontianak harus meningkatkan lagi pendapatan PAD agar kemandirian keuangan daerahnya semakin baik.

Dari Tabel 5 dapat dilihat bahwa rasio PAD terhadap TPD terus meningkat dari tahun 2011 sampai tahun 2014. Hasil rasio PAD terhadap TPD tertinggi adalah ditahun 2014 dengan nilai sebesar 20,54\%, dan yang terendah adalah di tahun 2011 dengan nilai sebesar $12,61 \%$. Jika dilihat secara rata-rata, hasil rasionya adalah 17,23\%. Dengan penurunan nilai rasio PAD terhadap TPD ini dan berdasarkan rata-ratanya dari tahun 2011-2014, menunjukkan bahwa kemampuan keuangan Kota Pontianak dapat dikatakan masih rendah.

Tabel 5. Derajat Desentralisasi Fiskal Kota Pontianak Tahun 2011-2014

\begin{tabular}{lccc}
\hline \multirow{2}{*}{ Tahun } & \multicolumn{3}{c}{ DDF (\%) } \\
\cline { 2 - 4 } & PAD/TPD & BHPBP/TPD & SBD/TPD \\
\hline 2011 & 12,61 & 65,19 & 23,39 \\
2012 & 16,41 & 58,90 & 24,67 \\
2013 & 19,38 & 61,27 & 19,34 \\
2014 & 20,54 & 56,12 & 22,60 \\
\hline
\end{tabular}




\begin{tabular}{llll}
\hline Rata-rata & 17,23 & 60,37 & 22,50
\end{tabular}

Adapun hasil perhitungan DDF yang ketiga, yakni rasio antara SBD terhadap TPD, nilai tertingginya adalah $65,19 \%$ pada tahun 2011 dan nilai terendah $56,12 \%$ pada tahun 2014. Sedangkan untuk rata-ratanya dari tahun 2011-2014, hasil rasio menunjukkan angka 60,37\%. Karena nilainya yang berada diatas 50\%, maka hal ini mengindikasikan bahwa ketergantungan Pemerintah Daerah Kota Pontianak finansial terhadap Pemerintah Pusat berkurang.

\subsubsection{Derajat Otonomi Fiskal (DOF)}

Kemandirian keuangan daerah (Otonomi Fiskal) menunjukkan kemampuan Pemerintah Daerah dalam membiayai sendiri kegiatan penyelenggaraan pemerintahan, pembangunan dan pelayanan kepada masyarakat yang telah membayar pajak dan retribusi sebagai sumber pendapatan yang diperlukan daerah (Halim, 2004). Derajat Otonomi Fiskal Kota Pontianak dihitung dengan menggunakan rasio antara bagian PAD (pajak daerah + retribusi daerah) dengan total belanja daerah.

Berdasarkan Tabel 6 dapat dilihat bahwa besarnya DOF Kota Pontianak tertinggi adalah pada tahun 2014 sebesar 17,80\% dan yang terendah pada tahun 2011 dengan nilai 10,23\%. Secara rerata, besarnya DOF Kota Pontianak adalah 15,69\%. Hal ini berarti kecenderungan kemampuan Pemerintah Daerah dalam membiayai sendiri kegiatan penyelenggaraan pemerintahan, pembangunan dan pelayanan kepada masyarakat masih rendah.

Tabel 6. Derajat Otonomi Fiskal Kota Pontianak Tahun 2011-2014

\begin{tabular}{crrrc}
\hline Tahun & Pajak Daerah & Retribusi Daerah & Total Belanja & DOF (\%) \\
\hline 2011 & $58.769 .561 .681,00$ & $18.305 .299 .499,00$ & $752.867 .063 .169,12$ & 10,23 \\
2012 & $117.806 .409 .735,00$ & $23.940 .468 .459,00$ & $891.672 .005 .596,75$ & 15,89 \\
2013 & $162.782 .492 .225,00$ & $26.992 .841 .239,50$ & $1.006 .492 .631 .240,15$ & 18,85 \\
2014 & $179.655 .427 .197,00$ & $53.412 .352 .739,63$ & $1.309 .158 .772 .458,49$ & 17,80 \\
\hline \multicolumn{5}{c}{ Rata-rata } \\
\hline
\end{tabular}

\subsubsection{Kebutuhan Fiskal (Fiscal Need/KbF)}

Kebutuhan Fiskal menggambarkan seberapa besar kebutuhan per kapita penduduk jika jumlah seluruh pengeluaran dibagi secara adil kepada seluruh penduduk daerah tersebut. Kebutuhan Fiskal juga menunjukkan besarnya indeks pelayanan publik per kapita. Kebutuhan Fiskal Kota Pontianak dan Propinsi Kalimantan Barat dapat di hitung menggunakan rumus (pengeluaran Kalbar : penduduk kalbar : jumlah kab/kota) untuk mencari KBF Kota Pontianak rumus ( Belanja tidak langsung Kota Pontianak : SKbF Kalbar). 
Dari Tabel 7 terlihat bahwa dari tahun 2011-2014 rata-rata kebutuhan fiskal standar se-Kalbar adalah sebesar Rp.3.094. adapun kebutuhan fiskal Kota Pontianak sebesar 169.357.128. Hal ini menunjukkan Indeks Pelayanan Publik Perkapita (IPPP) Kota Pontianak adalah sebesar 169.357.128 dan kebutuhan fiscal Kota Pontianak besar dari rata-rata kebutuhan standar se-Kalbar.

\subsubsection{Kapasitas Fiskal (Fiscal Capacity/KaF)}

Kapasitas Fiskal menunjukkan berapa besar usaha dari daerah yang diwujudkan dalam PDRB untuk memenuhi semua kebutuhannya, dalam hal ini adalah total pengeluaran daerah. Hasil dari indeks Kapasitas Fiskal menunjukkan seberapa besar hasil yang didapatkan oleh setiap penduduk dalam setiap daerah. Hasil perhitungan Kapasitas Fiskal Kota Pontianak dan Propinsi Kalimantan Barat pada Tabel berikut dengan menggunakan rumus ( PDRB HB Kalbar : jumlah penduduk Kalbar : jumlah Kab/kota ) sedangkan untuk mencari KaFPTK dengan menggunakan rumus ( PDRB HB PTK : jumlah penduduk PTK : SKaF Kalbar).

Tabel 7. Kebutuhan Fiskal (KbF) Se-Kalbar dan Kota Pontianak Tahun 2011-2014

\begin{tabular}{ccrcccr}
\hline Tahun & Pengeluaran Kalbar & Pengeluaran PTK Penduduk Kalbar Penduduk PTK SKbFKalbar & KbF PTK \\
\hline 2011 & $153.009 .098,000$ & $603.958 .638,80$ & 4.395 .983 & 554.764 & 2.486 & 155.708 .245 \\
2012 & 135.449 .301 .730 & $4.603 .958 .638,80$ & 4.460 .795 & 565.856 & 2.168 & 202.382 .195 \\
2013 & 333.302 .411 .000 & $20.603 .958 .638,80$ & 4.552 .345 & 575.843 & 5.229 & 93.163 .966 \\
2014 & 162.039 .565 .550 & $21.745 .959 .308,34$ & 4.641 .393 & 587.169 & 2.493 & 226.174 .106 \\
\hline \multicolumn{7}{c}{ Rata-rata } \\
\hline
\end{tabular}

Tabel 8 menunjukkan bahwa rata-rata kapasitas fiskal standar se- Kalbar dari tahun 2011-2014 adalah Rp 1.134. Sedangkan kapasitas fiskal standar Kota Pontianak sebesar 13,169. Bila dibandingkan, Kota Pontianak memiliki kapasitas fiskal yang lebih kecil dibanding kebutuhan fiskalnya $(13,169$ : 169.357.128). Selisih kurang ini diharapkan dapat ditutup melalui mekanisme transfer dari pemerintah pusat, sehingga dengan demikian Kota Pontianak masih mempunyai ketergantungan fiskal terhadap pemerintah pusat.

Tabel 8. Kapasitas Fiskal (KaF) Se-Kalbar dan Kota Pontianak Tahun 2011-2014

\begin{tabular}{crrrrrr}
\hline Tahun & PDRB HB Kalbar & PDRB HB PTK & Penduduk Kalbar Penduduk PTK & SKaF Kalbar & KaF PTK \\
\hline 2011 & $60.541 .582,28$ & $12.567 .866,77$ & 4.395 .983 & 554.764 & 983 & 11.327 \\
2012 & $66.915 .615,47$ & $13.913 .282,19$ & 4.460 .795 & 565.856 & 1.071 & 12.294 \\
2013 & $74.969 .657,05$ & $15.727 .004,22$ & 4.550 .297 & 575.843 & 1.176 & 13.655 \\
2014 & $84.956 .229,91$ & $18.086 .076,95$ & 4.641 .393 & 587.169 & 1.307 & 15.401 \\
\hline
\end{tabular}




\section{Rata-rata}

1.134

13.169

\subsubsection{Upaya/Posisi Fiskal (Tax Effort)}

Posisi Fiskal suatu daerah dihitung dengan mencari koefisien elastisitas PAD terhadap PDRB dengan rata-rata pertumbuhan selama kurun waktu tertentu dengan menggunakan rumus : (PAD tahun 2012 - 2011 : PAD tahun 2011) begitu juga dengan PDRB HK dan PDRB HB. Sedang rumus Elastisitas PAD= PAD : PDRB x i

Berdasarkan Tabel 9 dapat dihitung elastisitas PAD terhadap PDRB sehingga dapat diperoleh hasil sebagai berikut:

1. Elastisitas PAD terhadap PDRB ADHK $\frac{29,33}{6,18}=4,74$

2. Elastisitas PAD terhadap PDRB ADHB $\frac{29,33}{12,12}=3,40$

Tabel 9. Pertumbuhan PAD dan PDRB Kota Pontianak Tahun 2011-2014

\begin{tabular}{|c|c|c|c|c|c|c|}
\hline Tahun & PAD & $\% \triangle \mathrm{APAD}$ & PDRB HK & $\% \Delta$ PDRB HK & PDRB HB & $\% \triangle$ PDRB HB \\
\hline 2011 & $96.595 .549 .904,85$ & - & $30.328 .699,14$ & - & $60.541 .582,28$ & - \\
\hline 2012 & $151.139 .421 .187,94$ & 56,46 & $32.141 .382,11$ & 5,97 & $66.915 .615,47$ & 10,52 \\
\hline 2013 & $208.628 .660 .840,82$ & 38,03 & $34.007 .555,49$ & 5,80 & $74.969 .657,05$ & 12,03 \\
\hline 2014 & $256.271 .762 .170,33$ & 22,83 & $36.075 .103,43$ & 6,79 & 84.956.229,91 & 13,32 \\
\hline \multicolumn{2}{|c|}{ Rata-rata } & 29,33 & & 6,18 & & 12,1 \\
\hline
\end{tabular}

Dari hasil perhitungan di atas diketahui bahwa dengan menggunakan PDRB ADHK, laju pertumbuhan PDRB berpengaruh terhadap peningkatan PAD meskipun hanya kecil, yaitu bila PDRB meningkat $1 \%$ maka PAD akan meningkat sebesar $4,74 \%$. Sedangkan bila menggunakan PDRB ADHB, laju pertumbuhan PDRB juga hanya sedikit berpengaruh terhadap peningkatan PAD, yaitu apabila PDRB naik 1\% maka PAD akan meningkat sebesar $3,40 \%$.

\subsubsection{Rasio Efektivitas PAD}

Rasio Efektivitas menggambarkan kemampuan Pemerintah Daerah dalam merealisasikan PAD berdasarkan target yang telah ditetapkan sebelumnya, yang disesuaikan dengan potensi riil daerahnya. Kemampuan daerah dalam menjalankan tugas dan wewenangnya dikategorikan efektif bila rasio yang dicapai minimal sebesar 1 (satu) atau $100 \%$ (seratus persen). Semakin tinggi rasio efektivitas berarti menggambarkan kemampuan keuangan daerah yang semakin baik pula. Untuk mencari rasio efektifitas PAD dengan menggunakan rumus ( Realisasi PAD : Target PAD x 100\%). 
Tabel 10. Anggaran Pendapatan Asli Daerah (PAD) Kota Pontianak Tahun 2011-2014

\begin{tabular}{ccccc}
\hline Tahun & \multicolumn{2}{c}{ Pajak Daerah } & \multicolumn{2}{c}{ Retribusi daerah } \\
\cline { 2 - 5 } & Target & Realisasi & Target & Realisasi \\
\hline 2011 & $56.415 .000 .000,00$ & $58.769 .561 .681,00$ & $21.145 .436 .200,00$ & $18.305 .299 .499,00$ \\
2012 & $104.409 .000 .000,00$ & $117.806 .409 .735,00$ & $26.838 .924 .945,00$ & $23.940 .468 .459,00$ \\
2013 & $157.421 .000 .000,00$ & $162.782 .492 .225,00$ & $29.193 .705 .300,00$ & $26.992 .841 .239,00$ \\
2014 & $177.730 .000 .000,00$ & $179.655 .427 .197,00$ & $66.193 .057 .260,00$ & $53.412 .352 .739,63$ \\
\hline
\end{tabular}

Dalam anggaran pendapatan asli daerah Kota Pontianak dari tahun ke tahun selalu mengalami peningkatan dari pajak daerahnya dan retribusinya. Pajak daerah tertinggi pada tahun 2014 dengan jumlah 179.655.427.179,00 sedangkan yang rendah pada tahun 2011 berjumlah 58.769.561.681,00 dan retribusi yang tertinggi pada tahun 2014 dengan jumlah 53.412.352.739,63 sedangkan yang rendah terdapat pada tahun 2011 yang berjumlah 18.305.299.499,00. Dari itu Kota Pontianak dalam pendapatan asli daerahnya tiap tahunnya selalu mengalami peningkatan.

Dalam anggaran pendapatan asli daerah Kota Pontianak dari tahun ke tahun selalu mengalami peningkatan dari pajak daerahnya dan retribusinya. Laba Usaha Daerah tertinggi pada tahun 2014 dengan jumlah 8.553.670.659,30 sedangkan yang terendah pada tahun 2011 berjumlah 1.899.421.498,85 dan Lain-lain PAD yang tertinggi pada tahun 2014 dengan jumlah 23.650.311.574,40 sedangkan yang terendah terdapat pada tahun 2011 yang berjumlah 7.336.114.567,77. Dari itu Kota Pontianak dalam pendapatan asli daerahnya tiap tahunnya selalu mengalami peningkatan.

Tabel 11. Anggaran Pendapatan Asli Daerah (PAD) Kota Pontianak Tahun 2011-2014

\begin{tabular}{ccccc}
\hline \multirow{2}{*}{ Tahun } & \multicolumn{2}{c}{ Laba Usaha Daerah } & \multicolumn{2}{c}{ Lain-lain PAD } \\
\cline { 2 - 5 } & Target & Realisasi & Target & Realisasi \\
\hline 2011 & $2.035 .113 .704,85$ & $1.899 .421 .498,85$ & $17.000 .000 .000,00$ & $8.393 .981 .534,85$ \\
2012 & $2.237 .062 .638,17$ & $2.056 .428 .426,17$ & $8.332 .184 .650,00$ & $7.336 .114 .567,77$ \\
2013 & $2.790 .876 .038,42$ & $2.246 .318 .191,49$ & $18.089 .019 .750,00$ & $16.607 .009 .184,83$ \\
2014 & $9.190 .404 .786,64$ & $8.553 .670 .659,30$ & $54.932 .208 .290,00$ & $23.650 .311 .574,40$ \\
\hline
\end{tabular}

Tabel 12 menunjukkan bahwa secara rerata dari tahun 2011-2014, bagian penyusun PAD Kota Pontianak yang dapat dikategorikan kurang efektif karena rasio antara realisasi dengan target yang ditetapkan bernilai kurang dari dari $100 \%$.

Tabel 12. Rasio Efektivitas PAD Kota Pontianak Tahun 2011-2014

\begin{tabular}{|c|c|c|c|c|}
\hline \multirow[b]{2}{*}{ Tahun } & \multicolumn{4}{|c|}{ Bagian Daerah } \\
\hline & Pajak Daerah & Retri Daerah & Laba Usaha Daerah & Lain-lain PAD \\
\hline
\end{tabular}




\begin{tabular}{ccccc}
\hline 2011 & 104,17 & 86,56 & 93,33 & 49,37 \\
2012 & 112,83 & 89,20 & 91,92 & 88,04 \\
2013 & 103,40 & 92,46 & 80,48 & 91,80 \\
2014 & 101,08 & 80,69 & 93,07 & 43,05 \\
\hline Rata-rata & 105,37 & 87,22 & 89,70 & 68,06 \\
\hline
\end{tabular}

\subsubsection{Indikator Kinerja Pajak dan Retribusi}

Pos Pajak dan Retribusi merupakan pos yang memberikan sumbangan relatif besar terhadap PAD. Untuk mengetahui kinerja/kemampuan Pajak dan Retribusi dalam menghasilkan PAD, dapat diketahui dengan melihat besarnya Rasio Pengumpulan, Pertumbuhan, maupun Proporsi (Kontribusi) Pajak serta Retribusi Daerah. Semakin besar nilainya maka semakin besar pula kemampuan Pajak dan Retribusi Daerah dalam menghasilkan PAD.

1. Rasio Pengumpulan (Collection Ratio) Pajak dan Retribusi diperoleh dari perbandingan antara realisasi penerimaan Pajak dan Retribusi dengan targetnya. Rasio pengumpulan ini digunakan untuk mengukur efektivitas realisasi penerimaan Pajak dan Retribusi di wilayah Kota Pontianak. Untuk mencari rasio pengumpulan pajak menggunakan rumus (Realisasi Pajak : Target Pajak x 100\%) sedangkan untuk mencari pertumbuhan pajak dengan menggunakan rumus ( Realisasi Pajak : Target pajak daerah x 100\%).

Tabel 13. Rasio Pengumpulan Pajak Kota Pontianak Tahun 2011-2014

\begin{tabular}{clclc}
\hline \multirow{2}{*}{ Tahun } & \multicolumn{2}{c}{ Maksimal } & \multicolumn{2}{c}{ Minimal } \\
\cline { 2 - 5 } & Jenis Pajak & Nilai (\%) & \multicolumn{1}{c}{ Jenis Pajak } & Nilai (\%) \\
\hline $\mathbf{2 0 1 1}$ & Denda Pajak & 133,50 & Tunggakan Pajak & 91,75 \\
$\mathbf{2 0 1 2}$ & Denda Pajak & 125,43 & Tunggakan Pajak & 63,70 \\
$\mathbf{2 0 1 3}$ & Denda Pajak & 143,85 & Pajak Sarang Burung Walet & 24,76 \\
$\mathbf{2 0 1 4}$ & Pajak Hotel & 104,50 & Pajak Sarang Burung Walet & 6,18 \\
\hline
\end{tabular}

Dari Tabel 13 di atas dapat 3 tahun, yakni tahun 2011, 2012, dan 2013, rasio pengumpulan pajak diketahui bahwa dalam kurun waktu tertinggi dicapai oleh Denda Pajak. Secara keseluruhan rasio pengumpulan tertinggi dari tahun 2011-2014 dicapai oleh Denda Pajak pada tahun 2013 dengan nilai sebesar 143,85\%. Tapi pada tahun 2013 dan 2014, rasio pengumpulan pajak Sarang Burung Walet menjadi yang terendah dibandingkan pajak-pajak lainnya.

Tabel 14. Pertumbuhan Pajak Kota Pontianak Tahun 2011-2014

\begin{tabular}{lll}
\hline Tahun & Maksimal & Minimal \\
\hline
\end{tabular}




\begin{tabular}{llclc}
\hline & Jenis Pajak & Nilai (\%) & \multicolumn{1}{c}{ Jenis Pajak } & Nilai (\%) \\
\hline 2011 & Denda Pajak & 1,59 & Tunggakan Pajak & 0,10 \\
2012 & Denda Pajak & 1,66 & Tunggakan Pajak & 0,05 \\
2013 & Denda Pajak & 3,65 & Pajak Sarang Burung Walet & 0,07 \\
2014 & Pajak Hotel & 8,34 & Pajak Sarang Burung Walet & 0,08 \\
\hline
\end{tabular}

Pada Tabel 14 menggambarkan bahwa pada tahun 2011, 2012, 2013 dan tahun 2014 nilai pertumbuhan pajak tertinggi di Kota Pontianak dicapai oleh Pajak Hotel dengan nilai terbesarnya di tahun 2014 mencapai 8,34\%. Sedangkan nilai pertumbuhan pajak terendah di tahun 2012 dicapai oleh Tunggakan Pajak dengan pertumbuhan $0,05 \%$. Untuk mencari rasio pengumpulan retribusi dengan menggunakan rumus (realisasi retribusi : target retribusi x 100\%) sedangkan untuk mencari pertumbuhan retribusi daerah dengan rumus ( realisasi retribusi : target retribusi daerah x 100\%).

Berbeda dengan pajak, rasio pengumpulan retribusi baik yang mencapai nilai tertinggi maupun yang terendah dari tahun 2011-2014 selalu berbeda. Jika dilihat secara keseluruhan, nilai tertinggi untuk rasio pengumpulan retribusi dicapai pada tahun 2014 dengan jenis retribusi Retribusi Pengendalian Menara Telekomunikasi 169,44\%. Sedangkan nilai terendah untuk rasio pengumpulan retribusi terjadi pada tahun 2013 dengan jenis Retribusi Izin Usaha Perikanan 22,00\%.

Tabel 15. Rasio Pengumpulan Retribusi Kota Pontianak Tahun 2011-2014

\begin{tabular}{|c|c|c|c|c|}
\hline \multirow[t]{2}{*}{ Tahun } & \multicolumn{2}{|l|}{ Maksimal } & \multicolumn{2}{|c|}{ Minimal } \\
\hline & Jenis Retribusi & Nilai $(\%)$ & Jenis Retribusi & Nilai $(\%)$ \\
\hline 2011 & $\begin{array}{l}\text { Retribusi Pemeriksaan Alat } \\
\text { Pemadam Kebakaran }\end{array}$ & 102,55 & $\begin{array}{l}\text { Retribusi Izin Bidang } \\
\text { Postel }\end{array}$ & 39,05 \\
\hline 2012 & $\begin{array}{l}\text { Retribusi Pemeriksaan Alat } \\
\text { Pemadam Kebakaran }\end{array}$ & 120,02 & Retribusi Izin Trayek & 24,15 \\
\hline 2013 & $\begin{array}{l}\text { Retribusi Pemeriksaan Alat } \\
\text { Pemadam Kebakaran }\end{array}$ & 136,52 & $\begin{array}{l}\text { Retribusi Izin Usaha } \\
\text { Perikanan }\end{array}$ & 22,00 \\
\hline 2014 & $\begin{array}{l}\text { Retribusi Pengendalian Menara } \\
\text { Telekomunikasi }\end{array}$ & 169,44 & $\begin{array}{l}\text { Retribusi Izin Usaha } \\
\text { Perikanan }\end{array}$ & 29,60 \\
\hline
\end{tabular}

Tabel 16. Pertumbuhan Retribusi Kota Pontianak Tahun 2011-2014

\begin{tabular}{|c|c|c|c|c|}
\hline \multirow{2}{*}{ Tahun } & \multicolumn{2}{|l|}{ Maksimal } & \multicolumn{2}{|c|}{ Minimal } \\
\hline & Jenis Retribusi & Nilai (\%) & Jenis Retribusi & Nilai (\%) \\
\hline 2011 & $\begin{array}{l}\text { Retribusi Pemeriksaan Alat } \\
\text { Pemadam Kebakaran }\end{array}$ & 0,01 & $\begin{array}{l}\text { Retribusi Izin Bidang } \\
\text { Postel }\end{array}$ & 0,02 \\
\hline 2012 & $\begin{array}{l}\text { Retribusi Pemeriksaan Alat } \\
\text { Pemadam Kebakaran }\end{array}$ & 0,02 & Retribusi Izin Trayek & 0,01 \\
\hline 2013 & $\begin{array}{l}\text { Retribusi Pemeriksaan Alat } \\
\text { Pemadam Kebakaran }\end{array}$ & 0,02 & $\begin{array}{l}\text { Retribusi Izin Usaha } \\
\text { Perikanan }\end{array}$ & 0,01 \\
\hline 2014 & Retribusi Pengendalian & 0,05 & Retribusi Izin Usaha & 0,01 \\
\hline
\end{tabular}


Dari Tabel 16 tersebut di atas terlihat dari tahun ke tahun pertumbuhan masingmasing retribusi Kota Pontianak baik yang mencapai nilai tertinggi maupun yang terendah tidaklah sama. Secara keseluruhan pertumbuhan retribusi yang tertinggi dicapai pada tahun 2014 yakni retribusi pengendalian menara telekomunikasi dengan nilai pertumbuhan sebesar $0,05 \%$. Sedangkan pertumbuhan retribusi yang terendah adalah retribusi izin usaha perikanan 0,01\% di tahun 2013 dan 2014.

\subsubsection{Kemandirian Keuangan Daerah dan Pola Hubungan}

Kemandirian keuangan daerah menunjukkan kemampuan Pemerintah Daerah dalam membiayai sendiri penyelenggaraan pemerintahan, pembangunan dan pelayanan kepada masyarakat. Kemandirian keuangan daerah dapat juga menggambarkan sampai seberapa besar tingkat ketergantungan finansial Pemerintah Daerah terhadap Pemerintah Pusat. Kemandirian keuangan daerah Kota Pontianak dihitung dengan membandingkan penerimaan PAD terhadap penerimaan Bantuan dan Sumbangan Daerah.

Mengenai pola hubungan keuangan antara Pemerintah Pusat dan Pemerintah Daerah, ada 4 hubungan situasional yang dapat digunakan dalam pelaksanaan otonomi daerah Pola Hubungan Instruktif, dimana perananPemerintah Pusat lebih dominan daripada kemandirian Pemerintah Daerah (daerah yang tidak mampu melakasanakan otonomi daerah), 2) Pola Hubungan Konsultatif, dimana campur tangan Pemerintah Pusat sudah mulai berkurang karena daerah dianggap sedikit lebih mampu melaksanakan otonomi, 3) Pola Hubungan Partisipatif, dimana peran Pemerintah Pusat semakin berkurang, mengingat daerah yang bersangkutan tingkat kemandiriannya mendekati mampu melaksanakan otonomi daerah. 4) Pola Hubungan Delegatif, dimana campur tangan Pemerintah Pusat sudah tidak ada karena daerah telah benar-benar mampu dan mandiri dalam melaksanakan otonomi daerah.

Bertolak dari teori di atas, karena adanya potensi Sumber Daya Alam (SDA) dan Sumber Daya Manusia (SDM) yang berbeda akan menyebabkan perbedaan dalam tingkat kemandirian daerah dan pola hubungan antar daerah terhadap Pemerintah Pusat. Pola hubungan pemerintah pusat dan daerah serta tingkat kemandirian dan kemampuan keuangan daerah dapat disajikan dalam matriks seperti pada tabel berikut ini (Halim, 2007):

Tabel 17. Tingkat Kemampuan Keuangan, Kemandirian dan Pola Hubungan

\begin{tabular}{ccc}
\hline Kemampuan Keuangan & Kemandirian $(\%)$ & Pola Hubungan \\
\hline Rendah Sekali & $0-25$ & Instruktif \\
Rendah & $25-50$ & Konsultatif
\end{tabular}




\begin{tabular}{ccc} 
Sedang & $50-75$ & Partisipatif \\
Tinggi & $75-100$ & Delegatif \\
\hline
\end{tabular}

Untuk mengatahui tingkat kemandirian keuangan daerah Kota Pontianak digunakan analisis Rasio Kemandirian dengan rumus (Rasio Kemandirian = PAD : Bantuan + sumbangan + pinjaman $x 100 \%)$.

Dari Tabel tersebut terlihat bahwa kemandirian daerah Kota Pontianak dalam mencukupi kebutuhan pembiayaan untuk melakukan tugas-tugas pemerintahan, pembangunan dan pelayanan sosial masyarakat masih sangat rendah dan bahkan dari tahun 2011 sampai tahun 2013 cenderung mengalami peningkatan. Karena nilai rataratanya yang menunjukkan presentase di bawah 50\%, ini berarti Kota Pontianak memiliki pola hubungan yang bersifat Instruktif terhadap pemerintah pusat, dimana peranan pemerintah pusat lebih dominan dibanding kemandirian pemerintah daerah.

Tabel 18. Tingkat Kemandirian, Kemampuan Keuangan dan Pola Hubungan Kota Pontianak Selama Kurun Waktu 2011-2014

\begin{tabular}{crcccc}
\hline Tahun & PAD & $\begin{array}{c}\text { Bantuan+Sumbangan } \\
\text { +Pinjaman }\end{array}$ & $\begin{array}{c}\text { Rasio } \\
\text { Kemandirian }\end{array}$ & $\begin{array}{c}\text { Kemampuan } \\
\text { Keuangan }\end{array}$ & $\begin{array}{c}\text { Pola } \\
\text { Hubungan }\end{array}$ \\
\hline 2011 & $87.368 .264 .213,70$ & $678.331 .823 .980,47$ & 12,87 & Rendah Sekali & Instruktif \\
2012 & $151.139 .421 .187,94$ & $770.059 .958 .238,40$ & 19,62 & Rendah Sekali & Instruktif \\
2013 & $208.628 .660 .840,82$ & $867.716 .400 .990,36$ & 24,04 & Rendah Sekali & Instruktif \\
2014 & $26.271 .762 .170,33$ & $981.817 .784 .762,00$ & 27,01 & Rendah & Konsultatif \\
\hline \multicolumn{7}{r}{ Rata-rata } & & 21,22 & & \\
\hline
\end{tabular}

\section{PENUTUP}

\subsection{Kesimpulan}

Berdasarkan hasil analisis dan pembahasan, dalam penelitian ini dapat diambil kesimpulan sebagai berikut:

1. Analisis Kualitatif

a. Pertumbuhan APBD

Perhitungan APBD Kota Pontianak dari tahun 2011 sampai dengan tahun 2014 memperlihatkan adanya defisit anggaran yang berfluktuasi. Sedangkan pada tahun 2014 justru terjadi defisit anggaran yang rendah, jumlah defisit 62.069225.526,84 yang lebih besar daripada prosentase peningkatan pendapatan daerah.

b. Kontribusi PAD terhadap APBD

Dari tahun 2011-2014, kontribusi PAD terhadap APBD terus mengalami 
peningkatan.Hal ini menunjukkan semakin besarnya kontribusi selain PAD dalam menyumbang pendapatan daerah, misalnya saja bantuan dari pemerintah pusat ataupun pemerintah yang lebih tinggi.

2. Analisis Kuantitatif

a. Derajat Desentralisasi Fiskal (DDF)

Dari perhitungan DDF, yakni rasio antara PAD, BHPBP dan SBD terhadap TPD, menunjukkan bahwa secara rata-rata dari tahun 2011-2014 nilai kontribusi SBD terhadap TPD lebih dominan, bahkan kurang dari 50\% jika dibandingkan kontribusi PAD dan BHPBP terhadap TPD. Hal ini mengindikasikan ketergantungan Pemerintah Daerah Kota Pontianak terhadap Pemerintah Pusat baik maka tingkat ketergantungan finansial terhadap Pemerintah Pusat berkurang

b. Derajat Otonomi Fiskal (DOF)

DOF Kota Pontianak yang menunjukkan kemampuan Pemerintah Daerah Kota Pontianak dalam membiayai sendiri penyelenggaraan pemerintahan, pembangunan dan pelayanan kepada masyarakat cenderung mengalami kenaikan dari tahun 2011 sampai dengan tahun 2014. Jika dilihat rata-ratanya, besarnya DOF Kota Pontianak adalah 15,69\%. Ini menunjukkan kemampuan keuangan Kota Pontianak yang mulai mandiri..

c. Kebutuhan Fiskal (Fiscal Need)

Kebutuhan fiskal Kota Pontianak yang menggambarkan seberapa besar kebutuhan perkapita penduduknya adalah sebesar 169.357.128. Angka tersebut juga menunjukkan bahwa kebutuhan fiskal Kota Pontianak lebih besar dari ratarata kebutuhan standar se-Kalbar.

d. Kapasitas Fiskal (Fiscal Capacity).

Seberapa besar usaha dari suatu daerah yang diwujudkan dalam PDRB untuk memenuhi semua kebutuhannya tercermin dalam nilai kapasitas fiskal daerah tersebut. Kapasitas fiskal Kota Pontianak adalah sebesar 13.169. Jika dibandingkan, nilai kapasitas fiskal ini lebih kecil dari kebutuhan fiskalnya (13.169 : 169.357.128). Dan diharapkan selisih kurangnya dapat ditutup melalui mekanisme transfer dari pemerintah pusat. Dengan demikian Kota Pontianak masih mempunyai ketergantungan fiskal terhadap pemerintah pusat.

e. Upaya/Posisi Fiskal (Tax Effort)

Hasil perhitungan posisi fiskal Kota Pontianak dengan mencari koefisien elastisitas PAD terhadap PDRB dengan rata-rata pertumbuhan selama kurun waktu tertentu menunjukkan bahwa dengan menggunakan PDRB ADHK, laju pertumbuhan PDRB berpengaruh terhadap peningkatan PAD, yakni bila PDRB 
naik $1 \%$ maka PAD akan meningkat sebesar 4,47\%.Adapun bila menggunakan PDRB ADHB, pengaruh laju pertumbuhan PDRB terhadap peningkatan PAD adalah sebesar 3,40\%. Artinya, bila PDRB naik $1 \%$, PAD juga akan meningkat sebesar $3,40 \%$.

\section{f. Rasio Efektivitas PAD}

Berdasarkan reratanya, pos-pos bagian penyusun PAD yang terdiri dari pajak daerah, dapat dikategorikan efektif karena rasio antara realisasi dengan target yang telah ditetapkan sebelumnya lebih besar dari 100\%. Sedangkan bagian penyusun PAD yang berupa retribusi daerah secara rerata dari tahun 2011-2014 dapat dikategorikan tidak efektif karena hasil rasionya sebesar 87,22\%.

g. Indikator Kinerja Pajak dan Retribusi Daerah

Berdasarkan hasil perhitungan tingkat pertumbuhan dan nilai proporsi dari tiaptiap pos pajak/retribusi terhadap total pajak maupun retribusi dapat diambil kesimpulan sebagai berikut:

1. Pajak Daerah

Jenis pajak yang termasuk kategori:

a. Berkembang: pajak hotel, pajak reklame dan pajak hiburan.

b. Potensial: pajak BPHTB

c. Terbelakang: pajak sarang burung walet

2. Retribusi Daerah

Jenis retribusi yang termasuk kategori:

a. Prima: Retribusi izin mendirikan bangunan, retribusi pemeriksaan alat pemadam kebakaran, Retribusi Pelayananpersampahan/kebersihan.

b. Berkembang: Retribusi pelayanan persampahan/kebersihan, retribusi jasa umum, retribusi perizinan tertentu, retribusi izin mendirikan bangunan

c. Potensial: retribusi pelayanan persampahan/kebersihan, retribusi pasar, retribusi pelayanan kesehatan, retribusi pelayanan parkir tepi jalan umum dan retribusi

d. Terbelakang: retribusi pelayanan kesehatan hewan dan ikan, penjualan produksi usaha daerah, retribusi rumah potong hewan, retribusi Tanda Daftar Gudang (TDG), retribusi ijin usaha industri, retribusi pemeriksaan alat pemadam kebakaran, retribusi pengujian kendaraan bermotor, retribusi ijin trayek, retribusi pelayanan pemakaman, retribusi ijin gangguan, retribusi JU. tempat penginapan, retribusi tempat rekreasi dan olahraga, retribusi penyediaan usaha pariwisata serta retribusi pelayanan 
pencegahan bahaya kebakaran.

h. Kemandirian Keuangan Daerah

Rasio kemandirian daerah yang menggambarkan sampai seberapa besar tingkat ketergantungan financial pemerintah daerah terhadap pemerintah pusat, diperoleh dengan membandingkan penerimaan PAD terhadap penerimaan Bantuan dan Sumbangan Daerah. Dari tahun 2011-2014, rata-rata perhitungan rasio kemandirian Kota Pontianak menghasilkan nilai 21,22\% Karena nilainya yang berada diantara 0-25\%, maka Kota Pontianak dianggap memiliki kemampuan keuangan yang rendah sekali dan mempunyai pola hubungan instruktif terhadap pemerintah pusat, yang mana ketergantungan finansial terhadap pemerintah pusat masih rendah dibandingkan kemandirian daerahnya.

\subsection{Saran}

Dari hasil kesimpulan yang telah diuraikan di atas, saran yang dapat diambil terkait dengan penelitian ini adalah sebagai berikut:

1. Upaya pengoptimalan sumber-sumber PAD yang potensial masih sangat diperlukan dalam rangka mewujudkan kemandirian daerah Kota Pontianak.

2. Menciptakan daya tarik dan iklim yang kondusif bagi investor baik lokal maupun asing guna menanamkan modalnya di Kota Pontianak sehingga dapat meningkatkan laju pertumbuhan ekonomi daerah dan meningkatnya PDRB. Jika PDRB meningkat, maka pendapatan perkapita masyarakat meningkat dan akhirnya berdampak pada meningkatnya kemampuan masyarakat untuk membayar pajak.

3. Perusahaan daerah (BUMD) yang merupakan salah satu sumber pemasok dana ke kas daerah harus lebih profesional dalam melaksanakan tugasnya, sehingga kontribusinya bagi PAD juga akan meningkat.

\section{DAFTAR PUSTAKA}

Adisubrata, W. S. (2003). Perkembangan Otonomi Daerah di Indonesia (Sejak Proklamasi Sampai Awal Reformasi). Semarang: CV. Aneka Ilmu.

Bratakusumah, D. S., \& Solihin, D. (2002). Otonomi Penyelenggaraan Pemerintahan Daerah. Jakarta: PT. Gramedia Pustaka Utama.

Halim, A. (2004). Manajemen Keuangan Daerah (Edisi Revisi). Yogyakarta: UPP AMP YKPN. 
Halim, A., \& Damayanti, T. (2007). Pengelolaan Keuangan Daerah. Yogyakarta: UPP STIM YKPN

Kuncoro, M. (2000). Ekonomi Pembangunan (Teori, Masalah dan Kebijakan). Yogyakarta: UPP AMP YKPN.

Mardiasmo. (2004) Otonomi dan Manajemen Keuangan Daerah. Yogyakarta: Penerbit Andi

Mardiasmo. (2004). Otonomi dan Pembangunan Daerah. Jakarta: Erlangga.

Republik Indonesia. (2014). Undang-Undang No. 23 Tahun 2014 tentang Pemerintahan Daerah. Bandung: Citra Umbara.

Republik Indonesia. (2004). Undang-Undang No. 33 Tahun 2004 tentang Perimbangan Keuangan Antara Pemerintah Pusat dan Pemerintahan Daerah. Bandung: Citra Umbara.

Safi'i. (2007). Strategi dan Kebijakan Pembangunan Ekonomi Daerah (Perspektif Teoritik). Malang: Averroes Press.

Yuwono, S., Utomo, D. C., Zein, S. \& Azrafiany. (2008). Memahami APBD dan Permasalahannya (Panduan Pengelolaan Keuangan Daerah). Malang: Bayumedia Publishing. 